\title{
Vulvar Cancer PTX TNM Finding v7
}

National Cancer Institute

\section{Source}

National Cancer Institute. Vulvar Cancer PTX TNM Finding v7. NCI Thesaurus. Code C89419.

Vulvar cancer in which the primary tumor cannot be assessed. (from AJCC 7th Ed.) 